\title{
Radial variability of fibrovascular bundle properties of salacca (Salacca zalacca) fronds cultivated on Turi Agrotourism in Yogyakarta, Indonesia
}

\author{
LUTHFI HAKIM ${ }^{1,2, \bullet}$, RAGIL WIDYORINI ${ }^{3}$, WIDYANTO DWI NUGROHO ${ }^{3}$, TIBERTIUS AGUS PRAYITNO ${ }^{3}$ \\ ${ }^{1}$ Department of Forest Product Technology. Faculty of Forestry. Universitas Sumatera Utara. Jl. Tri Dharma Ujung No. 1 Kampus USU, Padang Bulan, \\ Medan 20155, North Sumatra, Indonesia. Tel./fax.: +62-61-8201920. "email: luthfi@usu.ac.id \\ ${ }^{2}$ JATI-Sumatran Forestry Analysis Study Center, Universitas Sumatera Utara. Jl. Tri Dharma Ujung No. 1 Kampus USU, Padang Bulan, Medan 20155, \\ North Sumatra, Indonesia \\ ${ }^{3}$ Department of Forest Product Technology, Faculty of Forestry, Universitas Gadjah Mada. Jl. Agro No. 1, Sleman 55281, Yogyakarta, Indonesia
}

Manuscript received: 9 July 2021. Revision accepted: 30 July 2021.

\begin{abstract}
Hakim L, Widyorini R, Nugroho WD, Prayitno TA. 2021. Radial variability of fibrovascular bundle properties of salacca (Salacca zalacca) fronds cultivated on Turi Agrotourism in Yogyakarta, Indonesia. Biodiversitas 22: 3594-3603. Fibrovascular bundles have properties variability not only based on species and varieties but also parts of species. This study, therefore, aims to characterize the FVB fundamental properties (anatomical, chemical, physical and mechanical) of Salacca zalacca (Gaertn.) Voss fronds, based on radial direction. The salacca fronds were divided into three parts, outer, middle as well as inner positions. Then the FVB's anatomical and physical properties were observed by light microscope and gravimetry analysis, respectively. Meanwhile, the variability of chemical and mechanical properties was investigated based on the ASTM standard. According to the results, the outer position has a higher variability of diameter, density, cellulose, lignin, and mechanical properties than the inner position, but has a lower hemicellulose value than the middle and inner position. Furthermore, the relationships between the anatomical, physical, chemical, and mechanical properties were discovered to form a pattern where increasing the mechanical properties is influenced by density and ratio vascular tissue area to total transverse area. Based on the results, the fibrovascular bundle of $S$. zalacca frond was concluded to possess anatomical, physical, chemical, and mechanical properties variability on the radial direction. There was a correlation between anatomical properties and mechanical properties.
\end{abstract}

Keywords: Fibrovascular bundles, frond, radial variability, salacca

Abbreviations: ASTM: American Society for Testing and Material, FA: Fiber Area, FVB: Fibro-Vascular Bundle, TA: Total Area, VA: Vascular Area

\section{INTRODUCTION}

In Indonesia, Salacca is an indigenous tree, with high species diversity, namely Salacca acehensis Mogea \& Zumaidar (Zumaidar et al. 2014), S. sumatrana (Becc) (Pareek and Sharma 2009), S. zalacca (Gaert.) Voss (Uji 2007), S. ramosiana Mogea (Mogea 1986), S. edulis Reinw, S. magnifica Mogea, S. sarawakensis Mogea, S. flabellata Furtado, and S. dransfieldiana Mogea (Mogea 1986). In addition, the tree also has been reported to possess high genetic diversity, as investigated by RAPDPCR (Random Amplified Polymorphic DNA- Polymerase Chain Reaction) (Budiyanti et al. 2015; Herawati et al. 2018; Elly et al. 2018), and based on morphological as well as phylogenetic relationships (Suskendriyati et al. 2000), and also variant diversity (Sumantra et al. 2014; Indah et al. 2019). Furthermore, salacca interacts with other organisms such as insects and fungi (Atmowidi et al. 2021; Rai et al. 2019; Siregar et al. 2021). Furthermore, the salacca fruit is edible with a sweet taste and contains a diversity of pharmacological properties (Saleh et al. 2018; Cepkova et al. 2021).
Salacca zalacca is a palms tree with an anatomical structure called a fibrovascular bundle (FVB), comprising sclerenchyma fiber, vascular, and parenchyma tissues functioning as reinforcement, water and nutrients circulation, as well as storage systems, respectively (Zhai et al. 2013; Syahirah et al. 2016; Hakim et al. 2019). A study by Zhai et al. (2013) disclosed FVB from monocot plants have characteristic variability on unique vascular tissues, in terms of type and shape. The vascular tissues, in turn, have relationships with other fundamental characteristics, including FVB diameter, density, and mechanical properties (Zhai et al. 2012: Hakim et al. 2019). However, information about the frond of the Salacca zalacca tree has not been widely reported.

The frond is one of the salacca tree's parts with an abundant FVB content. Hakim et al. (2019) reported the FVB of $S$. sumatrana and $S$. zalacca fronds to have diverse fundamental characteristics, including anatomical, chemical, physical and mechanical properties, and this variability is influenced by the differences in both species. Several other palm trees also exhibit this variability, for instance, FVB from bamboo (Darwis and Iswanto, 2018), leave sheet and anatomy of 18 palm species (Zhai et al. 
2013), anatomy of the coconut tree (Ahuja et al. 2014), windmill palm (Trachycarpus fortune) (Zhai et al. 2012), and Nypa fruticans (Tamunaidu and Saka 2011).

Numerous studies on FVB Properties variability based on species differences have been reported, but no studies have been reported based on species parts. Interestingly, $S$. zalacca is the largest population cultivated in Indonesia compared to other species (BPS, 2018). This study, therefore, investigates this variability based on frond radial orientation, in a bid to characterize the fundamental properties (anatomical, chemical, physical, and mechanical), based on the radial variability of salacca (Salacca zalacca (Gaertn.) Voss) frond.

\section{MATERIALS AND METHODS}

The major materials used in this study were fronds and fibrovascular bundles of Salacca zalacca Gaertn. (Voss), obtained from Turi agrotourism, Sleman district, Province of Yogyakarta, Indonesia. These fronds were harvested from the main stem at $10 \mathrm{~cm}$ from the bottom and divided into three positions, outer, middle, and inner positions (Figure 1), then soaked in water for 2 months to separate the FVBs.

\section{Anatomical and physical properties}

The specimens were cut at a thickness of $10-15 \mu \mathrm{m}$, and the FVB's cross-sectional areas were highlighted using safranin. Subsequently, a light microscope (Olympus BX 51, Tokyo, Japan) equipped with a digital camera (Olympus DP 70, Tokyo, Japan) was used to observe the anatomical properties with 10x magnification, while the imaging analysis software (ImageJ; v.1.46r) was then used to characterize FVB area. The analyzed areas were total area/TA (comprising sclerenchyma fibers and vascular tissues), fiber area/FA (comprising sclerenchyma fibers), and vascular area/VA (comprising vascular tissues). Figure 2 shows an illustration of the characterized FVB area. Several parameters were also measured to discover the relationship between the anatomical and mechanical properties. These are the ratio of the vascular area (VA) to the total area (TA), and the ratio of the fiber area (FA) to the total area (TA). Meanwhile, the FVBs' densities were measured using the method proposed by Munawar et al. (2007), and the diameter of each FVBs was evaluated using a handheld digital microscope (Dino-Lite edge 3.0 AM73915MZTL, New Taipei City, Taiwan) and analyzed using Dino-Lite software V.2.0.

\section{Chemical properties}

These were measured following the ASTM standard for measuring holocellulose content (ASTM D1104-56) cellulose and hemicellulose content (ASTM D1103-60), lignin content (ASTM D110-84), ash content (ASTM D1102-84), extractive solubility in hot water (ASTM D1110-84), extractive solubility in cold water (ASTM D1110-56), extractive solubility in ethanol-toluene (ASTM D1107-96) as well as extractive solubility in $1 \% \mathrm{NaOH}$.

\section{Mechanical properties}

The mechanical properties measured were maximum load, tensile strength, Young's modulus, specific tensile strength, specific Young's modulus, actual tensile strength, break, \% strain, and maximum stress. Based on the ASTM D-3379-75 (1989) test, the FVBs were discovered to have a moisture content of 8 to $12 \%$ wt. The percentage of moisture content is determined by the following equation:

$$
\% \mathrm{MC}=\frac{W a-W b}{w b} x 100 \%
$$

Where: \% MC is a moisture content of single FVB, $W a$ is initial weight $(\mathrm{g})$ and $W b$ is final weight $(\mathrm{g})$. The FVB's were then cut to a length of about $90 \mathrm{~mm}+0.1 \mathrm{~mm}$ and fixed on a $30 \mathrm{~mm}$ long paper frame using epoxy adhesive (ALF Epoxy adhesive, P.T Alfaglos, Semarang, Indonesia). The measurements were conducted in 100 replicates of single FVB for each position (outer, middle, and inner position). Figure 3 illustrates the mechanical properties testing using a universal testing machine (UTM Tensilon RTF 1350. Tokyo. Japan), with a $1 \mathrm{~mm} / \mathrm{min}$ crosshead speed. Before the test, the supporting paper's middle part was cut out, and then test mounting was carried according to the proposed by Hakim et al. (2019).

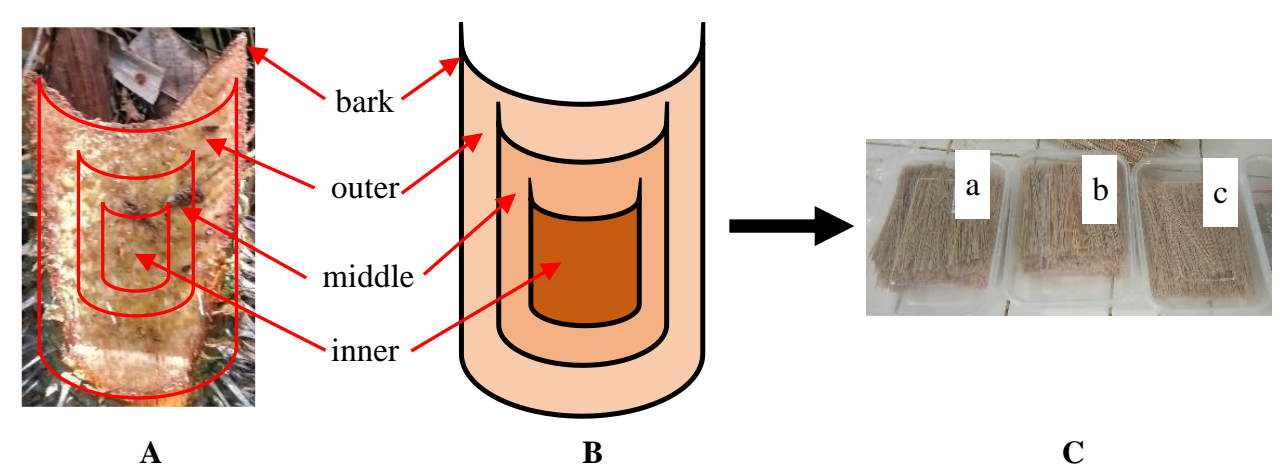

Figure 1. A. The radial section of a salacca frond. B. An illustration of the frond observed. C. Fibrovascular bundle were obtained from (a) outer (b) middle and (c) inner position 


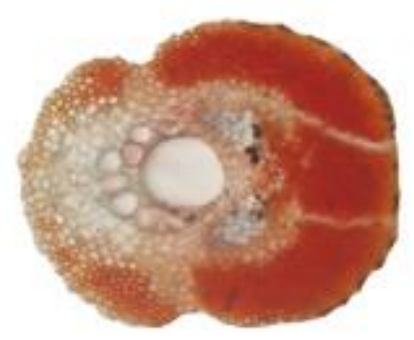

A

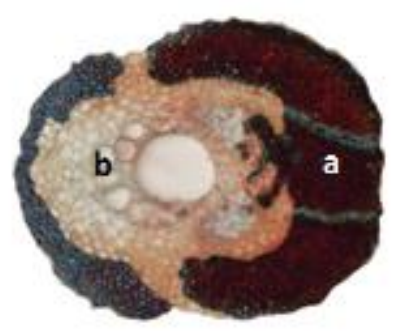

B

Figure 2. Illustration of characterized FVB area. Classification of (A) total areas/TA (includes fiber area and vascular area) and (B) a. fiber area/FA and b. vascular area/VA

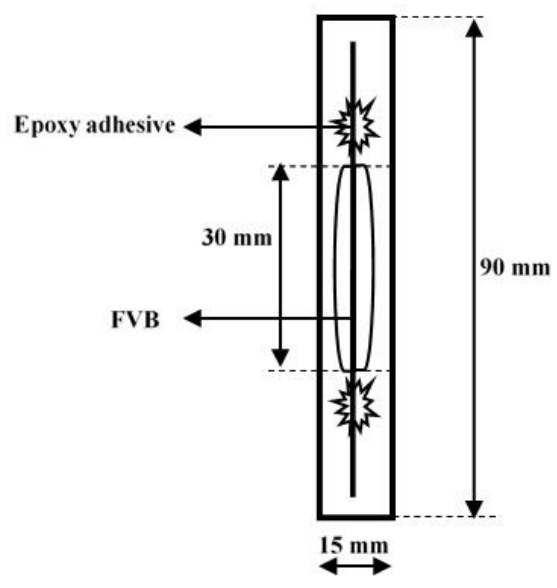

A
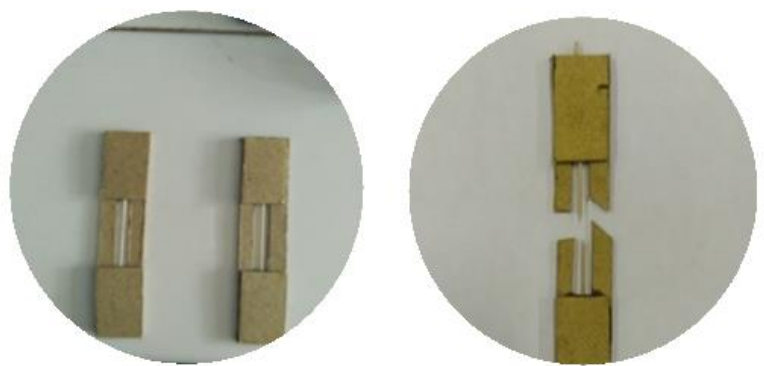

B

C

Figure 3. A. An illustration of the sample mounting on paper. B. sample before the test. C. sample after the test

\section{Statistical analysis}

Regression lines were used to analyze relationships between anatomical, physical (diameter, density, and ratio VA:TA) as well as mechanical properties (tensile strength and Young's modulus), while a Statistical analysis was performed using R-Studio software Version 4.0.0.

\section{RESULTS AND DISCUSSION}

\section{The variability of anatomical and physical properties}

Figure 4 shows the anatomical variability of $S$. salacca frond, where about 1-4 FVBs were discovered in every 4 $\mathrm{mm}^{2}$ of the sample. Generally, the outer frond had a greater density than the inner frond due to the number and density of FVB. The high population number and high density of FVB in the outer part can be assumed that the frond also has a high-density value. The fibrovascular bundles are larger and denser in the outer position (periphery), but reduce in size and density towards the middle and inner positions (Table 1). This pattern is similar to coconut (Fathi et al. 2014) and oil palm trunks (Darwis et al. 2013), where the number of vascular bundles decreases from the outside to the inside, but differs from bamboo trunks, where the inner FVB is larger, compared to the outer counterparts (Darwis and Iswanto 2018; Santhoshkumar and Baht 2014; Siam et al. 2019).

In addition, the outer vascular tissues were tighter, compared to the middle and inner counterparts. The vascular tissue functions as a transport system for water and nutrients within high porosity materials. Previous studies by Baley (2002) and Munawar et al. (2007) reported higher porosity on the FVB tissue implies reduced density. Meanwhile, Choowang (2018) reported the outer position of oil palm trunks (Elaeis guineensis Jacq.) has a higher density than the inner position. The density variability of FVB from $S$. salacca frond similar is similar to the coconut tree (Fathi et al. 2014; Srivaro et al. 2020) as well as oil palm trunk (Ramle et al. 2012; Abe et al. 2013; Srivaro et al. 2018a), and this density is influenced by percentage vascular area and fiber area. Srivaro et al. (2018b) stated anatomical variability in a palm tree depends on the size of the vascular bundle. This, in turn, depends on the number or size of fiber tissue, vessel, phloem, and parenchyma tissue comprising the FVB. 

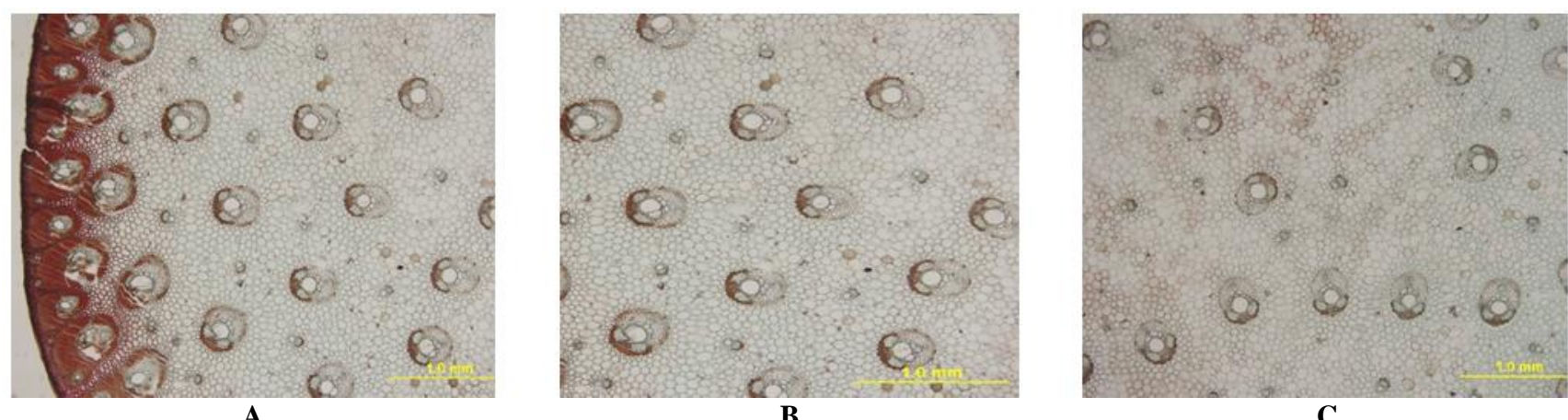

Figure 4. The anatomical variability on the radial direction of $S$. salacca frond. A. Outer position, B. Middle position, C. Inner position

Table 1. The variability of anatomical and physical properties of FVB S. zalacca frond

\begin{tabular}{|c|c|c|c|}
\hline \multirow{2}{*}{ Anatomical and physical properties of FVB } & \multicolumn{3}{|c|}{ Radial sections } \\
\hline & Outer position & Middle position & Inner position \\
\hline Diameter $(\mu \mathrm{m})$ & $43.96 \pm 2.07$ & $39.18 \pm 2.80$ & $32.25 \pm 5.09$ \\
\hline Density $\left(\mathrm{g} / \mathrm{cm}^{3}\right)$ & $0.44 \pm 0.06$ & $0.38 \pm 0.05$ & $0.37 \pm 0.06$ \\
\hline Number of FVB $\left(2 \times 2 \mathrm{~mm}^{2}\right)$ & $2-3$ & 2 & 1 \\
\hline \multicolumn{4}{|l|}{ Areas: } \\
\hline Total area of FVB/TA $\left(\mathrm{mm}^{2}\right)$ & $0.55+0.03$ & $0.49 \pm 0.04$ & $0.41 \pm 0.06$ \\
\hline Vascular area of FVB/VA $\left(\mathrm{mm}^{2}\right)$ & $0.06+0.02$ & $0.08+0.01$ & $0.11+0.01$ \\
\hline Fiber area /FA $\left(\mathrm{mm}^{2}\right)$ & $0.49 \pm 0.02$ & $0.41 \pm 0.03$ & $0.34 \pm 0.06$ \\
\hline Ratio of VA:TA $(\%)$ & $11.74 \pm 2.67$ & $15.92 \pm 1.76$ & $27.44 \pm 3.83$ \\
\hline Ratio of FA:TA (\%) & $88.26 \pm 2.67$ & $84.08 \pm 1.76$ & $72.56 \pm 3.83$ \\
\hline
\end{tabular}

Table 2. The variability of frond and FVB chemical content

\begin{tabular}{|c|c|c|c|c|c|c|}
\hline \multirow{2}{*}{ Chemistry content of FVB } & \multicolumn{2}{|c|}{ Outer position } & \multicolumn{2}{|c|}{ Middle position } & \multicolumn{2}{|c|}{ Inner position } \\
\hline & Frond & FVB & Frond & FVB & Frond & FVB \\
\hline Cellulose & 39.3 & 42.3 & 39.5 & 41.5 & 38.7 & 39.1 \\
\hline Hemicellulose & 28.3 & 33.3 & 27.5 & 34.9 & 31.3 & 36.2 \\
\hline Lignin & 23.0 & 29.6 & 22.7 & 29.2 & 21.6 & 28.4 \\
\hline Hot water solubility & 14.7 & 3.1 & 14.5 & 3.0 & 14.8 & 3.0 \\
\hline Coldwater solubility & 12.2 & 2.9 & 12.4 & 2.8 & 12.8 & 2.8 \\
\hline $1 \% \mathrm{NaOH}$ solubility & 21.5 & 4.7 & 22.4 & 5.2 & 24.2 & 5.7 \\
\hline Ethanol-toluene solubility & 7.8 & 15.4 & 8.3 & 14.7 & 9.4 & 14.6 \\
\hline Ash content & 2.3 & 1.3 & 2.4 & 1.4 & 2.7 & 1.4 \\
\hline
\end{tabular}

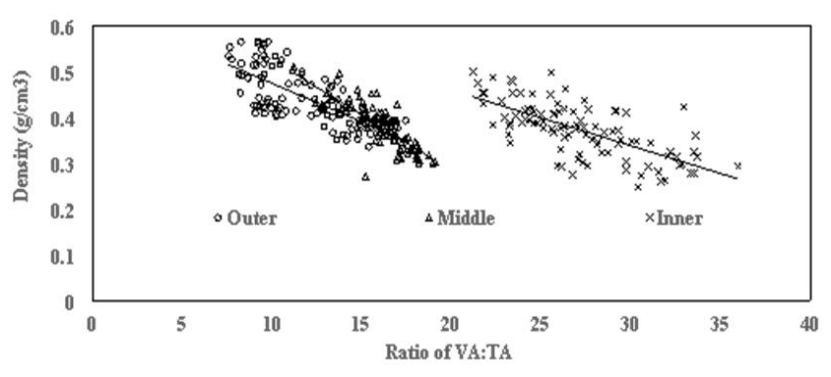

Figure 5. The relationship between VA:TA ratio and density of FVB $S$. zalacca frond

The VA:TA ratio was lower in the outer position, but increased towards the middle and inner positions. Conversely, the FA:TA ratio was higher in the outer position but decreased towards the middle and inner positions. Furthermore, a relationship was discovered between the VA:TA ratio and FVB density, where one value decreases with an increase in the other. This is because vascular tissues contain transport cells (vessels) due to high porosity and decreasing fiber density, while a high content of non-vascular tissue indicates high density (Baley 2002; Munawar et al. 2007). Figure 5 shows the relationship between FVB density and VA:TA ratio. Based on the diagram, the large content of vascular tissue in the transverse section causes an increase in the FVB density, and the presence of fiber tissue significantly positively influences this density contributes, but negatively influenced by the presence of vessels, vascular tissue, and parenchyma (Charquist 2012). Also, vascular tissues are one of the factors causing increased porosity, and consequently, reduced density in FVB (Zhai et al. 2013). 


\section{The variability of chemistry properties}

The cellulose and lignin contents in the frond and FVB tended to decrease from the outer to the inner position (Table 2). This is probably because cellulose and lignin are the most prevalent FVB fiber tissues. However, in some cases, the number and non-vascular area of FVB decreased from the inner to the outer position, meaning the cellulose and lignin components were also reduced. Meanwhile, the extractive solubility and the hemicellulose and ash contents tended to increase towards the inner position. The extractive content is dominated by easily dissoluble substances contained in the parenchyma tissue.

Previous studies contained a little discussion of variations in chemical properties based on the radial position in the palm frond, however, several studies have reported differences in characteristics based on plant parts. Dungani et al. (2016) reported that the whole oil palm frond has an $\alpha$-cellulose content of $54.5 \%$. The other palms, Tamunaidu and Saka (2011) as well as Astuti et al. (2020), reported variations in chemical properties within various parts of the Nypa fruticans, where the highest cellulose, hemicellulose, and lignin contents were found in the frond, compared to the coir and fruit shell. Similarly, Saadaoui et al. (2013) discovered variations between the chemical properties of oil palm fronds, fruit stalk, and leaves. This study successfully discovered the cellulose contents of the sheath (50.6\%), fruit stalk (39.8\%), frond (34.0\%), and leaves (29.7\%). In addition, the highest hemicellulose and lignin contents were discovered in the leaves, and sheath, respectively, while the cellulose content was found to increase from the outer to the inner position.

\section{The variability of mechanical properties}

Table 3 shows the variability of the mechanical properties of FVB from S. zalacca frond based on the radial direction. According to the table, the maximum load, tensile strength, and modulus of elasticity are higher in the outer position than the middle and inner counterparts. The outer position had higher tensile strength $(223.96 \mathrm{MPa})$, compared to the middle (198.17 MPa) and inner (185.84 $\mathrm{MPa}$ ) counterparts, respectively. Also, the external modulus of elasticity (2.02 GPa) was higher, compared to the middle (1.64 MPa) and inner (1.62 MPa) counterparts, respectively. Darwis et al. (2013) disclosed that the oil palm trunk has stronger vascular bundles on the outer position than the inner counterparts. Meanwhile, salacca FVB has lower tensile strength and modulus of elasticity, compared to natural fibers (Zhu et al. 2019), and these values are higher, compared to non-wood natural fibers (Srivaro et al. 2018b) and some fibrovascular bundles of several other palms investigated by Zhai et al. (2013). The fibrovascular bundle has vascular tissue that plays a role in reducing strength, which is why the mechanical properties of FVB are lower than those of natural fibers, while natural fibers are composed purely of sclerenchyma fibers.

The stress-strain (S-S) curves of the FVB from the inner, outer, and middle positions of $S$. zalacca frond had values of 5.97\%; 5.57\%; and 4.37\%, respectively (Figure 6), and all straight-line S-S curves are truly elastic (Duval et al. 2011). A downward trend in variation was also observed from the outer to the inner position. These results are similar to Zhai et al. (2012) report, where the greater strain was observed in the outer part of FVB from windmill palm (Trachycarpus fortunei). The greater strain is in the outer part because the fiber area is larger than the vascular area (Table 1). The fiber area is composed of sclerenchyma fibers that function as a reinforcement of FVB.

\section{The variability of the relationship between diameter and mechanical properties}

Figure 7 shows the variations in the relationship between diameter and mechanical properties of FVB $S$. zalacca. These variations indicate there is no uniformity within the regression pattern in the relationship between diameter and mechanical properties. The outer position of the frond shows an increase in FVB diameter is bound to reduce the mechanical properties, while the middle and inner positions show an increase in the diameter improves the mechanical properties. Interestingly, several other factors influence the mechanical properties, such as density and ratio of vascular tissue area and fiber tissue area). Statistically, the R-square percentage is also minute, indicating a weak correlation between diameter and mechanical properties. Meanwhile, a high statistical significance is shown in 3 regression equations. These are the relationship between diameter and tensile strength of the outer and the middle positions and the relationship between the middle position's diameter and Young's modulus.

Table 3. The variability of Mechanical properties of FVB

\begin{tabular}{llll}
\hline Mechanical properties & Outer position & Middle position & Inner position \\
\hline Maximum load (kgf) & $12.8 \pm 1.75$ & $10.00 \pm 2.07$ & $7.76 \pm 2.53$ \\
Maximum stress (Mpa) & 71.18 & 61.28 & 51.12 \\
Strain (\%) & 5.97 & 5.57 & 4.37 \\
Tensile strength (MPa) & $223.96 \pm 33.38$ & $198.17 \pm 33.27$ & $185.84 \pm 49.19$ \\
Young's modulus (GPa) & $2.02 \pm 0.44$ & $1.64 \pm 0.33$ & $1.62 \pm 0.33$ \\
Specific tensile strength (MPa) & $506.10 \pm 50.37$ & $516.41 \pm 49.07$ & $496.73 \pm 84.62$ \\
Specific Young's modulus (GPa) & $4.53 \pm 0.72$ & $4.25 \pm 0.44$ & $4.37 \pm 0.54$ \\
Actual tensile strength (MPa) & $253.10 \pm 32.60$ & $234.74 \pm 36.41$ & $253.40 \pm 56.78$ \\
\hline
\end{tabular}


Zhai et al. (2012) disclosed the cell wall thickness of sclerenchyma fibers plays a major role in the mechanical properties of FVB from windmill palm (Trachycarpus fortune). However, the vascular tissues in the FVB tend to reduce mechanical properties. Therefore, the radial area of the fibrovascular bundle comprising vascular and nonvascular (sclerenchyma fibers) tissues, is a key factor in the mechanical properties' effect on the FVB. This means the ratio of vascular to non-vascular tissue is a determinant factor in the mechanical properties and diameter.

\section{The variability of the relationship between density and mechanical properties}

Figure 8 shows the variations in the relationship between density and mechanical properties of FVB from $S$. zalacca frond. According to the diagram, there was a similar pattern of regression trend for each position in the frond, where a rise in density is bound to improve the mechanical properties of FVB. Li and Shen (2011) and Hakim et al. (2019) reported a similar variation in the relationship between the two variables. The same trend was observed in FVBs from coconut (Fathi and Frühwald 2014), oil palm (Darwis et al. (2013), and bamboo (Santhoshkumar and Bath, 2014). Interestingly, all previous studies stated higher density in the outer position is possibly associated with a higher number of vascular bundles and a higher proportion of fiber tissue (Zhai et al. 2013; Hakim et al. 2019). Thus, there is a higher density distribution on the outer position than the inner counterpart, leading to an increase in mechanical properties from the inside to the outside.

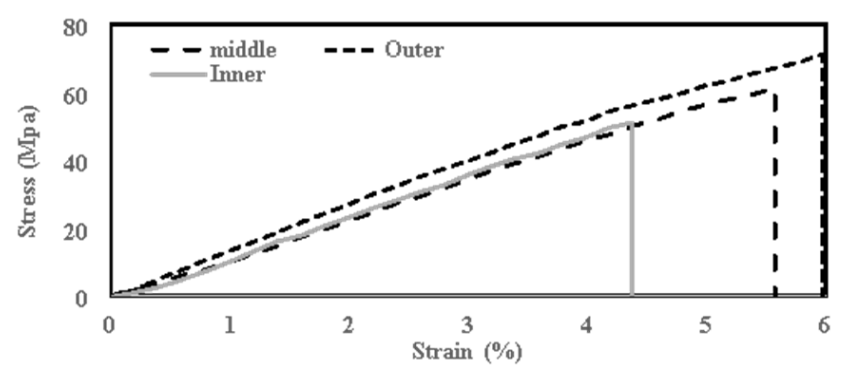

Figure 6. The variability of stress-strain (S-S) curve of FVB $S$. zalacca frond

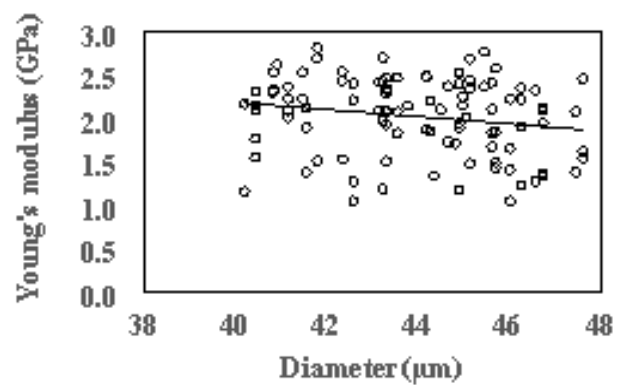

$\mathbf{A}$

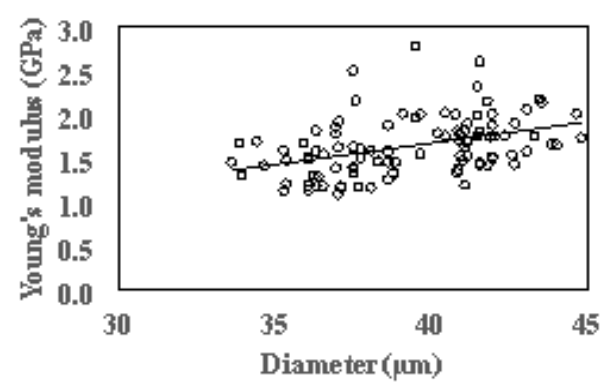

B

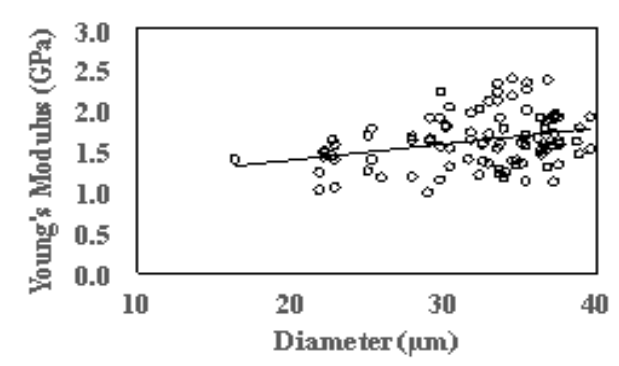

C

Figure 7. The variability of the relationship between the diameter and mechanical properties of FVB from $S$. salacca frond. A. Outer position, B. Middle Position, C. Inner position 

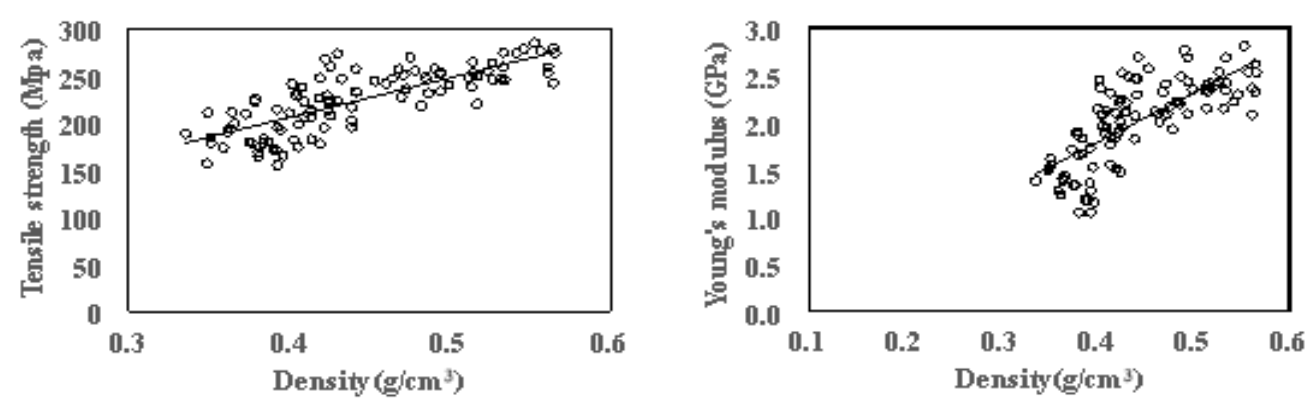

A
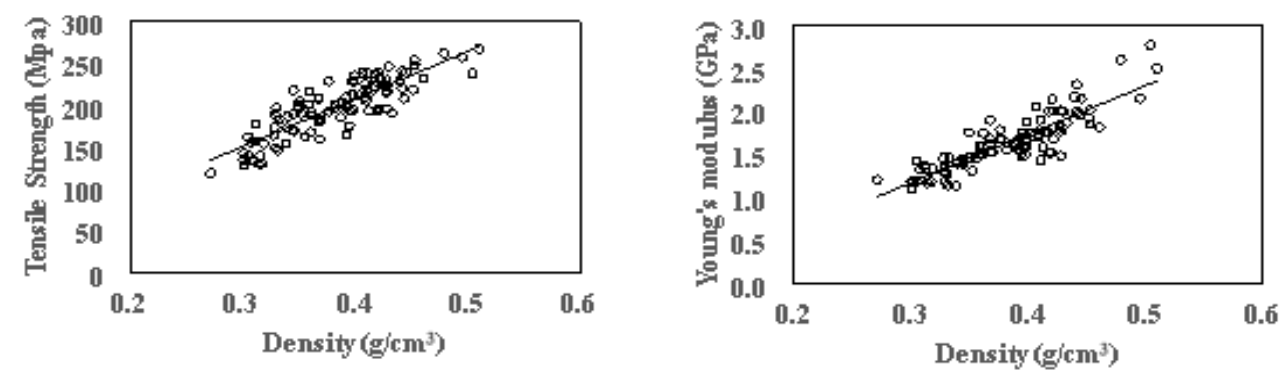

B
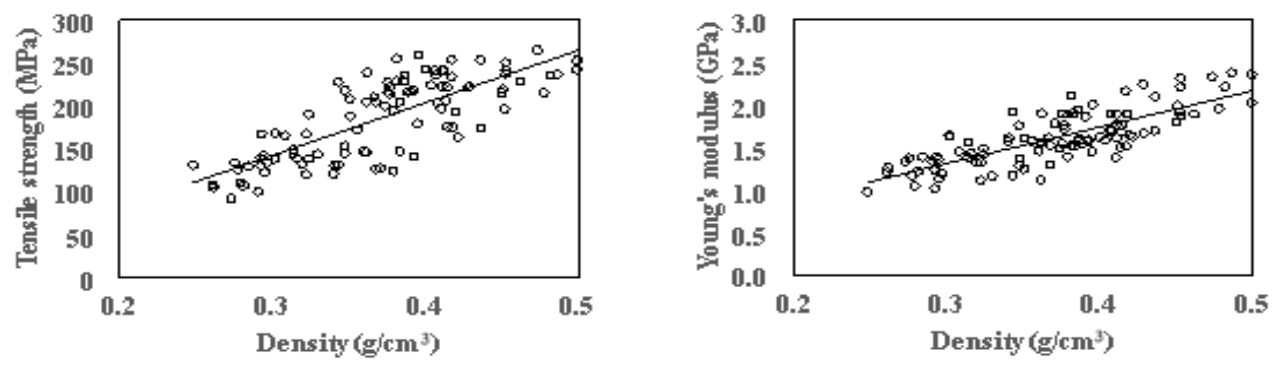

C

Figure 8. The relationship variability between the density and mechanical properties of FVB from S. salacca frond. A. Outer position. B. Middle Position. C. Inner position.

The same trend of high R-square values (above 50\%) was observed in the outer, middle, and inner positions of the FVB from $S$. zalacca frond, indicating a high statistical significance for all three positions. Therefore, density significantly influences the mechanical properties of the FVB, and the two variables are strongly correlated. This is probably because the density of FVB is influenced by sclerenchyma fibers with thick cell walls dominated by cellulose.

\section{The variability of the relationship between VA:TA ratio and mechanical properties}

Figure 9 shows the variation in the relationship between the VA:TA ratio and mechanical properties of FVB fronds from $S$. zalacca. The regression pattern shows an increase in the VA:TA ratio leads to a reduction in mechanical properties (tensile strength and Young's modulus), indicating the ratio of vascular to non-vascular tissue has a role in influencing the mechanical properties. As reported in previous studies, there is a decrease in the percentage of fiber tissue from the outer to the inner position (Zhai et al. 2013; Santhoshkumar and Bath 2014). Based on the regression pattern, the FVB's density was influenced by the VA:TA ratio, and this, in turn, implies FVB's mechanical properties. An increase in this ratio indicates a rise in porosity, due to the high and low percentages of vascular tissue and sclerenchyma, respectively.

Statistically, the R-square values for all FVB positions were above $50 \%$, indicating the VA:TA ratio is a factor influencing the strong mechanical properties of FVB. The high statistical significance also supports this for all VA:TA ratio regression equations for all three positions.

In conclusion, the variability of anatomical, physical, chemical, and mechanical properties is influenced by the position of the frond's radial direction. The anatomical and physical variability properties consisted of the number, size, and density of fibrovascular bundle (FVB). The outer part of FVB has higher density compared to the inner part. Furthermore, the physical and anatomical properties (diameter, density, and VA:TA ratio) in FVB influence the mechanical properties (tensile strength and Young's modulus). The density and VA:TA ratios strongly influence the mechanical properties, while diameter has a weak influence. 

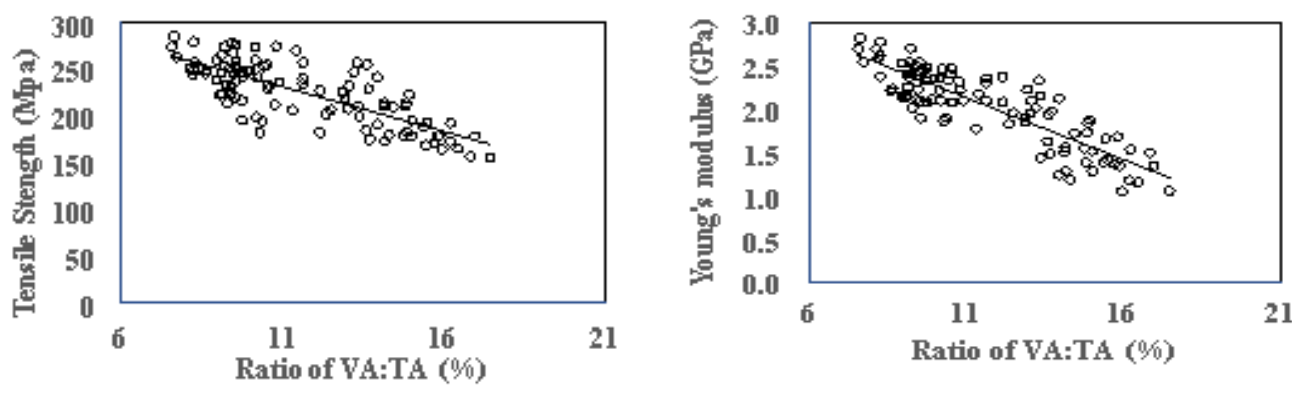

A
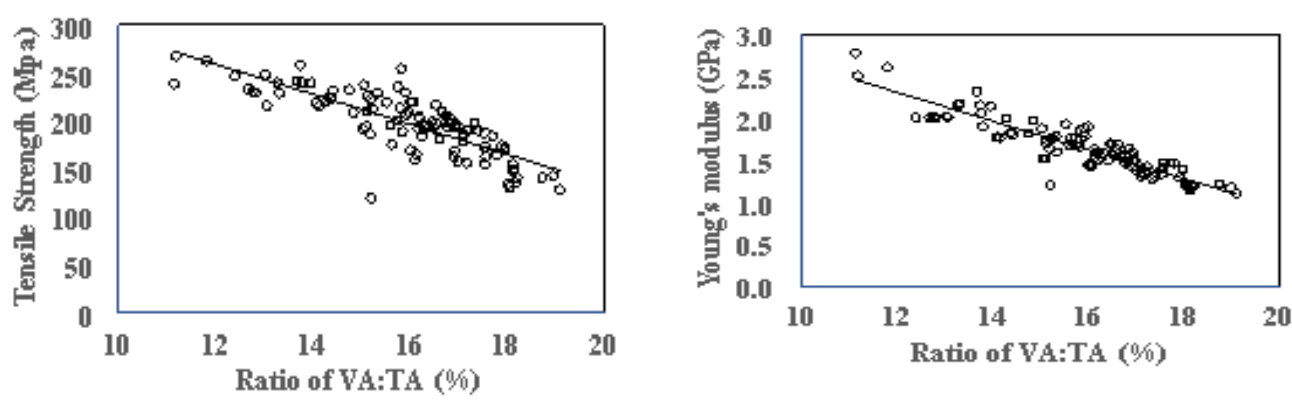

B
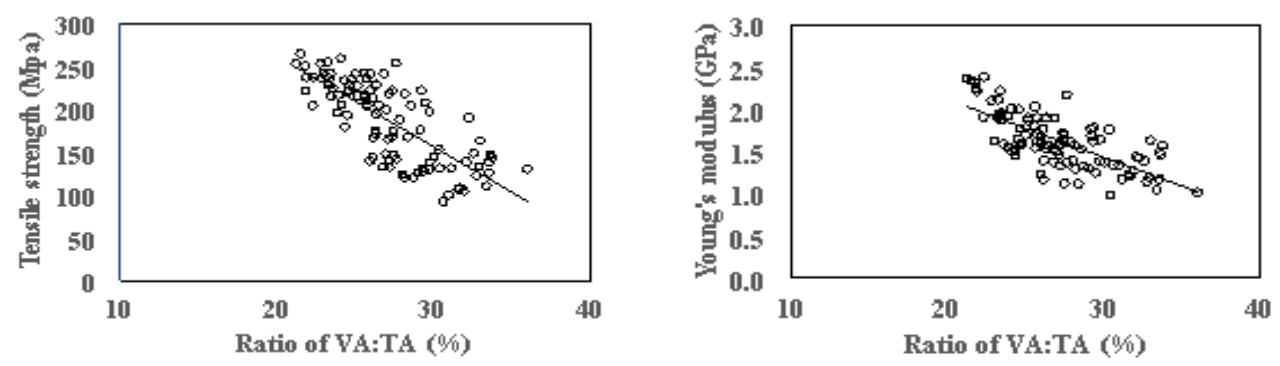

C

Figure 9. The relationship variability between the VA:TA ratio and mechanical properties of FVB from S. salacca frond. A. Outer position, B. Middle Position, C. Inner position

\section{ACKNOWLEDGEMENTS}

The authors are grateful to Ministry of Education, Culture, Research and Technology, Republic of Indonesia.

\section{REFERENCES}

Abe H, Murata Y, Kubo S, Watanabe K, Tanaka R, Sulaiman O, Hashim R, Ramle SFM, Zhang C, Noshiro S, Mori Y. 2013. Estimation of the ratio of vascular bundles to parenchyma tissue in oil palm trunks using NIR Spectroscopy. Bioresources 8 (2): 1573-1581.

Ahuja SC, Ahuja S, Ahuja U. 2014. Coconut history, uses, and folklore Asian Agri-History (18) 3: 221-248.

ASTM D 1102-84. 2001. Standard test method for ash in wood. ASTM International West Conshohocken, USA.

ASTM D 3379-75. 1989. Standard test method for tensile strength and Young's modulus for high-modulus single-filament materials. ASTM International, West Conshohocken, USA.

ASTM D1103-84. 2013. Standard test method for alfa-cellulose in wood. ASTM International, West Conshohocken, USA.

ASTM D1104-84. 2013. Standard test method for holocellulose in wood ASTM International, West Conshohocken, USA.
ASTM D1105-96. 2013. Standard test method for preparation of extractive-free wood. ASTM International, West Conshohocken, USA.

ASTM D1106-84. 2013. Standard test method for Acid insoluble lignin in wood. ASTM International, West Conshohocken, USA.

ASTM D1110-84. 2013. Standard test method for water solubility of wood. ASTM International, West Conshohocken, USA.

Astuti MD, Nisa K, Mustikasari K. 2020. Identification of chemical compounds from Nipah (Nypa fruticans Wurmb.) Endosperm. Proceeding: $1^{\text {st }}$ International Conference on Tropical Wetland Biodiversity and Conservation (ICWEB 2019). BIO Web of Conf 20: 03002. DOI: 10.1051/bioconf/20202003002.

Atmowidi T, Kahono S, Dorly, Rahmawati SD, Reinaldo D, Ummah ES. 2021. The diversity of insect visitors on Indonesian salacca (Salacca spp.) in Mekarsari fruits garden, Bogor, Indonesia. Acta Univ Agric Silvic Mendelianae Brun 69 (2): 267-273. DOI: 10.11118/actaun.2021.024

Budiyanti T, Hadiati S, Prihatini R, Sobir. 2015. Genetic diversity of Indonesian snake fruits as food diversification resources. Intl $\mathrm{J}$ Adv Sci Eng Inform Technol 5 (3): 41-44. DOI: 10.18517/ijaseit.5.3.513

Carlquist S. 2012. Monocot Xylem Revisited: New Information, New Paradigms. Bot Rev 78: 87-153. DOI 10.1007/s12229-012-9096-1.

Cepkova PH, Jagr M, Janovska D, Dvoracek V, Kozak AK, Viehmannova I. 2021. Comprehensive Mass Spectrometric Analysis of Snake Fruit: Salak (Salacca zalacca). J Food Qual 2021: 6621811. DOI: $10.1155 / 2021 / 6621811$. 
Choowang R. 2018. Correlation of the areal number density of vascular bundles with the mechanical properties of oil palm wood (Elaeis guineensis Jacq.). Wood Res J 9 (1): 4-7. DOI: 10.51850/wrj.2018.9.1.4-7.

Darwis A and Iswanto AH. 2018. Morphological characteristics of Bambusa vulgaris and the distribution and shape of vascular bundles therein. J Korean Wood Sci Technol 46 (4): 315-322. DOI: 10.5658/WOOD. 2018.46.4.315.

Darwis A, Nurrochmat DR, Massijaya MY, Nugroho N, Alamsyah EM, Bachtiar ET, Safe'i R. 2013. Vascular bundle distribution effect on density and mechanical properties of oil palm trunk. Asian J Plant Sci 12 (5): 208-213. DOI: 10.3923/ajps.2013.208.213.

Dungani R, Owolabi AF, Saurabh CK, Khalil HPSA, Tahir PM, Hazwan CICM, Ajijolakewu KA, Masri MM, Rozamah E, Aditiwati P. 2016 Preparation and fundamental characterization of cellulose nanocrystal from oil palm fronds biomass. J Polymer Environ 25: 692-700. DOI: 10.1007/s10924-016-0854-8.

Duval A, Bourmaud A, Augier L, Baley C. 2011. Influence of the sampling area of the stem on the mechanical properties of hemp fibers. Mater Lett 65: 797-800. DOI: 10.1016/j.matlet.2010.11.053.

Elly SS, Watuguly TW, Rumahlatu D. 2018. Short Communication: Genetic diversity of Salacca edulis from West Seram District, Maluku, Indonesia based on morphological characters and RAPD profiles. Biodiversitas 19 (5): 1777-1782. DOI 10.13057/biodiv/d190526.

Fathi L, Frühwald A, Koch G. 2014. Distribution of lignin in vascular bundles of lignification and tensile strength in single UVspectroscopy and relationship between coconut wood (Cocos nucifera) by cellular vascular bundles. Holzforschung 68 (8): 915925. DOI: 10.1515/hf-2013-0213.

Hakim L, Widyorini R, Nugroho WD, Prayitno TA. 2019. Anatomical, chemical, and mechanical properties of fibrovascular bundles of Salacca (Snake Fruit) Frond. BioResources 14 (2): 7943-57. DOI: 10.15376/biores.14.4.7943-7957.

Herawati W, Amurwanto A, Nafi'ah Z, Ningrum AM, Samiyarsih S. 2018. Variation analysis of three Banyumas local salak cultivars (Salacca zalacca) based on leaf anatomy and genetic diversity. Biodiversitas 19 (1): 119-125. DOI: 10.13057/biodiv/d190118.

Indah NK, Indriyani S, Arumingtyas EL, Azrianingsih R. 2019. Phenetic Relationship of pasuruan snake fruits (Salacca zalacca (Gaertn.) Voss. Proceeding: The 9th International Conference on Global Resource Conservation (ICGRC) and AJI from Ritsumeikan University. AIP Conference Proceedings 2019: 020011-1-020011-5. DOI: $10.1063 / 1.5061847$.

Mogea JP. 1986. A new spesies in the genus Salacca. Principes 30 (4) 161-164.

Pareek OP and Sharma S. 2009. Underutilized fruit and nuts. Vol. 2: Fruit and tropical region. Aavishkar Publishers, India

Rai IN, Suada IK, Proborini MW, Wiraatmaja IW, Semenov M, Krasnov G. 2019. Indigenous endomycorrhizal fungi at salak (Salacca zalacca) plantations in Bali, Indonesia and their colonization of the roots. Biodiversitas 20 (8): 2410-2416. DOI: 10.13057/biodiv/d200840.

Ramle SFM, Sulaiman O, Hashim R, Arai T, Kosugi A, Abe H, Murata Y, Mori Y. 2012. Characterization of parenchyma and vascular bundle of oil palm trunk as function of storage time. Lignocellulose 1 (1): 33 44.

Saadaoui N, Rouilly A, Fares K, Rigal L. 2013. Characterization of date palm lignocellulosic by-products and self-bonded composite materials obtained thereof. Mater Design 50: 302-308. DOI: 10.1016/j.matdes.2013.03.011
Saleh MSM, Siddiqui MJ, Mediani A, Ismail NH, Ahmed QU, So'ad, SZM, Besbes SS. 2018. Salacca zalacca: A short review of the palm botany, pharmacological uses and phytochemistry. Asian Pac J Trop Med 11 (12): 645-652. DOI: 10.4103/1995-7645.248321.

Santhoshkumar R, Bath KV. 2014. Variation in density and its relation to anatomical properties in bamboo culms, Bambusa bambos (L) Voss. J Plant Sci 2 (3): 108-112. DOI: 10.11648/j.jps.20140203.12

Siam NA, Uyup MKA, Husain H, Mahmod AL, Awalluddin MF. 2019. Anatomical, physical and mechanical properties of thirteen Malaysian bamboo species. BioResources 14 (2): 3925-3943.

Siregar MRI, Sitepu SF, Siregar AZ. 2021. Insects diversity in salak (Salacca zalacca Gaert.) plantation with differences altitude in North Sumatra, Indonesia. Proceeding: International Conference on Agriculture, Environment and Food Security. IOP Conf Ser Earth Environ Sci 782: 042036: 1-5. DOI: 10.1088/17551315/782/4/042036

Srivaro S, Matan N, Lam F. 2018a. Property gradients in oil palm trunk (Elaeis guineensis). J Wood Sci 64: 709-719. DOI: 10.1007/ s10086018-1750-8.

Srivaro S, Rattanarat J, Noothong P. 2018b. Comparison of the anatomical characteristics and physical and mechanical properties of oil palm and bamboo trunks. J Wood Sci 64: 186-192. DOI: 10.1007/s10086017-1687-3.

Srivaro S, Tomad J, Shi J, Cai J. 2020. Characterization of coconut (Cocos nucifera) trunk's properties and evaluation of its suitability to be used as raw material for cross laminated timber production. Construct Build Mater 254: 1-14. DOI: 10.1016/j.conbuildmat.2020.119291

Sumantra IK, Pura ILNS, Ashari S. 2014. Heat unit, phenology and fruit quality of Salak (Salacca zalacca var. amboinensis) cv. Gulapasir on different elevations in Tabanan regency-Bali. Agric For Fish 3 (2): 102-107. DOI: 10.11648/j.aff.20140302.18.

Suskendriyati H, Wijayati A, Hidayah N, Cahyuningdari D. 2000. Studies on morphological and phylogenetic relationship of salak pondoh varieties (Salacca zalacca (Gaert.) Voss.) at Sleman Highlands. Biodiversitas 1 (2): 59-64. DOI: 10.13057/biodiv/d010204.

Syahirah MN, Noraini T, Latiff A. 2016. Characterization of Midrib Vascular Bundles of Selected Medicinal Species in Rubiaceae. Proceeding: The 2016 UKM FST Postgraduate Colloquium. AIP Conf Proc 1784: 060042-1-060042-4. DOI: 10.1063/1.4966880.

Tamunaidu P, Saka S. 2011. Chemical characterization of various parts of nipa palm (Nypa fruticans). Industr Crops Prod 34 (3): 1423-1428. DOI: $10.1016 /$ j.indcrop.2011.04.020.

Uji T. 2007. Species diversity of indigenous fruits in Indonesia and its potential: a Review. Biodiversitas 8(2): 156-167.

Zhai S, Imai T, Horikawa Y, Sugiyama J. 2013. Anatomical and mechanical characteristics of leaf-sheath fibrovascular bundles in palms. IAWA J 34 (3): 285-300. DOI: 10.1163/22941932-00000024.

Zhai S, Li D, Pan B, Sugiyama J, Itoh T. 2012. Tensile strength of windmill palm (Trachycarpus fortunei) fiber bundles and its structural implications. J Mater Sci 47 (2): 949-959. DOI: 10.1007/s10853-0115874-0.

Zhu J, Li J, Wang C, Wang H. 2019. Anatomy of the Windmill Palm (Trachycarpus fortunei) and Its Application Potential. Forests 10 (12): 1130. DOI: $10.3390 / \mathrm{f} 10121130$

Zumaidar, Chikmawati T, Hartana A, Sobir, Mogea JP, Borchsenius F. 2014. Salacca acehensis (Arecaceae), A new species from Sumatra, Indonesia. Phytotaxa 159 (4): 287-290. DOI: 10.11646/phytotaxa.159.4.5. 